Mini Review

\title{
SEA BUCKTHORN LEAVES AND THE NOVEL FOOD EVALUATION
}

\author{
Sanna Kauppinen \\ Natural Resources Institute Finland (Luke), Lönnrotinkatu 3, 50100 Mikkeli, FINLAND; \\ sanna.kauppinen@luke.fi
}

Communicated by Dalija Segliṇa

\begin{abstract}
Novel food means any food that was not used for human consumption to a significant degree within the European Union before 1997. The novel food regulation (EC) 258/97 concerns also foods and food ingredients consisting of or isolated from plants, except the food having a history of safe food use within the European Union before 1997. According to the knowledge thus far, sea buckthorn (Hippophae rhamnoides L.) leaves have not been used to a significant degree as food, food supplement, or spice in European Union before 1997. The new regulation on novel foods (EU) No. 2015/2283 (Anonymous, 2015) comes into force in the beginning of 2018. After that also history of safe use in a third country is accepted as information of its traditional use. This means continued use for at least 25 years in the customary diet of a significant number of people. Novel food application has to include the description of the product, production process, characteristics and composition, proposed uses and use levels, anticipated intake, history of its use, absorption, distribution, metabolism, excretion, nutritional and toxicological information and allergenicity. Sea buckthorn leaves have been under active research lately and a lot of information is already available, but safety assessment required for novel food evaluation may still be needed.
\end{abstract}

Key words: EU regulation, Hippophaè rhamnoides, non-traditional food, safety assessment.

\section{INTRODUCTION}

Novel food means any food that was not used for human consumption to a significant degree within the European Union before 1997. Regulation (EC) 258/97 on novel foods and novel food ingredients was adopted to protect public health by subjecting novel foods to a safety assessment through an EU procedure before they are placed on the market within the EU. The regulation came into force 1997 and this year was decided to be the deadline for the traditional food use.

If a food was commercialised in at least one Member State before 15 May 1997, it can be marketed elsewhere in the EU under the "principle of mutual recognition" and the Novel Food Regulation does not apply. If the significant history of use before 1997 in EU can be found, then this data has to be shown to authorities and they evaluate if it is a traditional food. If there has not been significant food use, then in order to get it legally on the EU market as a food, application with safety assessment needs to be done.

Sea buckthorn (Hippophae rhamnoides L.) is a well-known plant, which has a great nutritional and medical potential (Suryakumar and Gupta, 2011). Its berries and oil have a long tradition of use in East Asia (Rousi, 1971). Also in Europe berries have been used as food in countries where sea buckthorn grows naturally (Rousi, 1971). Recently also other parts of the plant have been under research and especially leaves have shown similar nutritional and medicinal effects to those of berries (Suryakumar and Gupta, 2011). According to the author's knowledge, thus far sea buckthorn leaves have not been used to a significant degree as food, food supplement, or spice in European Union before 1997. The aim of this paper is to introduce the scope and procedure of Novel Food Regulation and what it may mean for the food use of sea buckthorn leaves.

\section{DEFINITION OF NOVEL FOOD IN REGULATION FROM THE YEAR 1997}

Novel food is food that has not been used for human consumption to a significant degree within the Union before the date of entry into force of Regulation on novel foods and novel food ingredients (EC) 258/97, which is 15 May 1997, and is

- genetically modified food

- food with a new or intentionally modified molecular structure

- food from microorganisms, fungi or algae 
- foods and food ingredients consisting of or isolated from plants and food ingredients isolated from animals, except for foods and food ingredients obtained by traditional propagating or breeding practices and having a history of safe food use (Anonymous, 1997b).

So even if the plant has been produced in a traditional way, but it does not have a history of safe food use within the European Union before 1997, it is considered as novel food. For example, stevia leaves are not accepted as food, because they do not have a history of use in the EU, and not even as novel food because safety assessment has been insufficient (Anonymous, 2013). The regulation originally contained rules on genetically modified organisms (GMOs), but these were taken out of the regulation on 2003 when the EU adopted a more specific regulation on GMOs (Regulation (EC) 1829/2003; Anonymous, 2003). The use for human consumption to a significant degree is defined in a separate document (Anonymous 1997a).

\section{DEFINITION OF NOVEL FOOD ACCORDING TO REG- ULATION FROM THE YEAR 2015}

Regulation on novel foods (EU) 2015/2283 (Anonymous, 2015) that comes into force on 1 January 2018 defines also that novel food is food that has not been used for human consumption to a significant degree within the Union before the date of entry into force of Regulation on novel foods and novel food ingredients (EC) 258/97, which is 15 May 1997 , and is

- food with a new or intentionally modified molecular structure

- food from cell culture or tissue culture derived from animals, plants, microorganisms, fungi or algae

- food from microorganisms, fungi or algae

- food from material of mineral origin

- food consisting of engineered nanomaterials

- food from animals that are not produced by traditional breeding practices

- food consisting of, isolated from, or produced from plants or their parts, except when the food has a history of safe food use within the Union and the plant is produced by traditional propagating practices or non-traditional, but without changing the composition of the plant

- but if the food has history of use outside EU it is considered as traditional food also in European Union. History of use outside EU means that it has been consumed in at least one third country for at least 25 years as a part of the customary diet of a significant number of people (Anonymous, 2016a).
SEA BUCKTHORN LEAVES: HISTORY OF USE BEFORE 1997 AND TO DATE

Sea buckthorn leaves have been used as a feed to horses in Ancient Greece, we all know this, but have there been any human consumption before 1997 in the EU? In the Baltic countries common use of leaves as a tea started in the beginning of $21^{\text {st }}$ century (author's own, unpublished research). It seems that also, for example, in Hungary and Germany the use as a tea started later than 1997. After 1997, the use as a tea in several EU countries has started and sea buckthorn leaves for tea can be found in stores. No documents of other use has been found to date.

In East Asia the main product of sea buckthorn has been berry and its juice and oil. No much information about ancient use of leaves can be found. In Russia or former Soviet Union several patents about leaves can be found (Russian National Library database for the research of patents): leaf oil, granulated tea, method for producing serotonin, non-alcoholic beverage. Commercial products in Russia are Giporamin (Hiporaminum), which is an antiviral medicine made of dry purified extract from sea buckthorn leaves (patent from the year 1994, Shipulina et al., 1998), mixture of leaf and berry oil, and leaves for tea. It seems like sea buckthorn leaves have been used more for medicinal purpose than for food.

\section{SEA BUCKTHORN LEAVES: USE IN THE FUTURE?}

Sea buckthorn leaves have a huge potential in animal feed, cosmetics, food additives, food supplements, food and food ingredients because of its wide-ranging and rich composition of healthy ingredients (Kashif \& Ullah, 2013; Morgenstern et al., 2014; Hellström et al., 2015). Its mild taste gives possibilities to use it as tea, but also as green powder for example in bread, smoothie, pills and capsules. Different regulations control the use for different purposes. For the animal feed there is Regulation (EC) 767/2009 (Anonymous, 2009a), on the placing on the market and use of feed. Regulation (EC) 1223/2009 (Anonymous, 2009b) is on cosmetics, Regulation (EC) 1333/2008 (Anonymous, 2008) on food additives, and Regulation (EC) 258/97 on novel food and food supplements. Also, Directive 2002/46/EC (Anonymous, 2002) is related to food supplements. This list of regulations is not comprehensive and exact information can be obtained from authorities in each country. Sea buckthorn leaf extract is accepted as feed supplement to animals in EU (Anonymous, 2010), but no other use is known to be accepted to date.

\section{PROCESS OF NOVEL FOOD EVALUATION}

The Novel Food Catalogue maintained on the Internet by the European Commission lists products of animal and plant origin and other substances subject to the Novel Food Regulation, based on information provided by the EU Member States. It is a non-exhaustive list and serves as orientation 
on whether a product will need an authorisation under the Novel Food Regulation. The catalogue can be amended by submitting information to the national authorities of the respective EU country for verification, e.g., the history of significant consumption of a food or food ingredient prior to 15 May 1997 in the EU. According to the catalogue, at the moment only the use of the fruits (berries) of Hippophae rhamnoides as food or food ingredient is known in the EU.

If no history of consumption can be proved, then the food or food ingredient cannot legally be marketed in the EU until the necessary authorisation has been issued. A novel food application is first made to a single EU Member State. Scientific information and safety assessment report has to be submitted. The Member State has 90 days to produce an initial opinion. This opinion is then circulated to all EU Member States, who are then given a further 60 days to comment or make a reasoned objection. If there are no objections, the novel food will be authorised (or rejected) at the end of the 60 days in line with the initial opinion. If necessary, the European Food Safety Authority (EFSA) will first be asked for its opinion on any outstanding safety questions.

Novel food application has to include description of the product, production process, characteristics and composition, proposed uses and use levels, anticipated intake, history of its use, and safety assessment which includes absorption, distribution, metabolism, excretion, nutritional and toxicological information and allergenicity (Anonymous, 2016b). Safety assessment is the most expensive part of the application if not enough proper research results are already available.

There are not many plants or plant parts that have been authorised as novel food, but some examples can be found. Coriander seed oil was authorised as novel food in 2013 (Agostoni et al., 2013) and noni fruit puree and concentrate were authorised in 2009 (Bresson et al., 2009).

\section{CONCLUSION}

The status of sea buckthorn leaves is at the moment unclear with regard to novel food. Inclusive research of traditional use should be compiled before the status can be approved. In every research concerning sea buckthorn leaves attention should be paid to measuring of parameters valuable for safety assessment and publishing those results so that relevant information for novel food applications will be available in the future.

\section{REFERENCES}

Anonymous (1997a). Human Consumption to a Significant Degree. Information and Guidance Document. Available at:

http://ec.europa.eu/food/safety/docs/novel-food_guidance_human-consumption_en.pdf (accessed 25 September 2016).

Anonymous (1997b). Regulation (EC) No. 258/97 of the European Parliament and of the Council of 27 January 1997 concerning novel foods and novel food ingredients. Official Journal L, 043, 14.02.1997, 0001-0006. Available at:
http://eur-lex.europa.eu/LexUriServ/LexUriServ.do?uri=CELEX:31997R 0258:en:HTML (accessed 25 September 2016).

Anonymous (2002). Directive 2002/46/EC of the European Parliament and of the Council of 10 June 2002 on the approximation of the laws of the Member States relating to food supplements. Official Journal L, 183, 12.07.2002, 51-57. Available at:

http://eur-lex.europa.eu/eli/dir/2002/46/oj (accessed 25 September 2016).

Anonymous (2003). Regulation (EC) No. 1829/2003 of the European Parliament and of the Council of 22 September 2003 on genetically modified food and feed. Official Journal L, 268. Available at: http://eur-lex.europa.eu/eli/reg/2003/1829/oj (accessed 5 August 2016).

Anonymous (2013). Petition 0041/2013 by Jos Eisberg (German) on the approval of stevia. Committee on Petitions. Notice to Members. Available at: http://www.europarl.europa.eu/meetdocs/2009_2014/documents/peti/cm/1015/1015893/1015893en.pdf (accessed 8 October 2016).

Anonymous (2008). Regulation (EC) No. 1333/2008 of the European Parliament and of the Council of 16 December 2008 on food additives. Official Journal L, 354, 31.12.2008, 16-33. Available at:

http://eur-lex.europa.eu/eli/reg/2008/1333/oj (accessed 25 September 2016).

Anonymous (2009a). Regulation (EC) No. 767/2009 of the European Parliament and of the Council of 13 July 2009 on the placing on the market and use of feed. Official Journal L, 229, 01.09.2009, 1-28. Available at: http://eur-lex.europa.eu/eli/reg/2009/767/oj (accessed 25 September 2016).

Anonymous (2009b). Regulation (EC) No. 1223/2009 of the European Parliament and of the Council of 30 November 2009 on cosmetic products. Official Journal L, 342, 22.12.2009, 59-209. Available at:

http://eur-lex.europa.eu/eli/reg/2009/1223/oj (accessed 25 September 2016).

Anonymous (2010). Seabuckthorn leaf extract. (Search with the word seabuckthorn written together). Feed Materials Register. Available at: http://www.feedmaterialsregister.eu/ (accessed 8 October 2016).

Anonymous ((2015). Regulation (EU) No. 2015/2283 of the European Parliament and of the Council of 25 November 2015 on novel foods. Official Journal L, 327, 11.12.2015, 1-22. Available at:

http://eur-lex.europa.eu/eli/reg/2015/2283/oj (accessed 25 September 2016).

Anonymous (2016a). Draft guidance on the preparation and presentation of a notification for authorisation of Traditional Foods from third countries. EFSA Panel on Dietetic Products, Nutrition and Allergies (NDA). Available at: http://www.efsa.europa.eu/sites/default/files/consultation/160218a.pdf (accessed 8 October 2016)

Anonymous (2016b). Novel Food Catalogue. Available at: http://ec.europa.eu/food/safety/novel_food/catalogue/search/public/index.cfm (accessed 25 September 2016).

Agostoni, C., Berni Canani, R., Fairweather-Tait, S., Heinonen, M., Korhonen, H., La Vieille, S., Marchelli, R, Martin, A., Naska, A., Neuhäuser-Berthold, M., Nowicka, G., Sanz, Y., Siani, A., Sjödin, A., Stern, M., Strain, S. (J. J.), Tetens, I., Tomé, D., Turck, D., Verhagen, H. (2013). Scientific Opinion on the safety of "coriander seed oil" as a Novel Food ingredient. EFSA Panel on Dietetic Products, Nutrition and Allergies (NDA). EFSA Journal, 11 (10), 3422. Available at: http://onlinelibrary.wiley.com/doi/10.2903/j.efsa.2013.3422/full (accessed 25 September 2016).

Bresson, J.-L., Flynn, A., Heinonen, M., Hulshof, K., Korhonen, H., Lagiou, P., Løvik, M., Marchelli, R., Martin, A., Moseley, B., Przyrembel, H., Salminen, S., Strain, J. (S.), Strobel, S., Tetens, I., van den Berg, H., van Loveren, H., Verhagen, H. (2009). Opinion on the safety of Tahitian Noni ${ }^{\circledR}$ 'Morinda citrifolia (noni) fruit puree and concentrate' as a novel food ingredient. Scientific opinion of the panel on dietetic products, nutrition and allergies. EFSA Journal, 998, 1-16. Available at: http://onlinelibrary.wiley.com/doi/10.2903/j.efsa.2009.998/epdf (accessed 25 September 2016). 
Hellström, J., Pihlava, J.-M., Kauppinen, S. (2015). Phytosterols and flavonols in sea buckthorn leaves. In: Kauppinen, S., Petruneva, E. (eds.). Producing Sea Buckthorn of High Quality. Proceedings of the $3^{\text {rd }}$ Workshop on Sea Buckthorn EuroWorkS2014. Natural resources and bio-economy studies, 31, 50-53. Available at: http://urn.fi/URN:ISBN:978-952-326-035-1 (accessed 8 October 2016).

Hellström, J., Pihlava, J.-M., Marnila, P., Mattila, P., Kauppinen, S. (2014). Sea buckthorn leaves - processing waste rich in valuable phytochemicals. In: Mörsel, J.-T., Zubarev, Y., Eagle, D. (eds.). Seabuckthorn - Research for a Promising Crop. BoD Print Norderstedt, pp. 101-103.

Kashif, M., Ullah, S. (2013). Chemical composition and minerals analysis of Hippophae rhamnoides, Azadirachta indica, Punica granatu, and Oximum sanctum leaves. World J. Dairy Food Sci., 8, 67-73.

Received 10 October 2016

Accepted in the final form 22 May 2017
Morgenstern, A., Ekholm, A., Scheewe, P., Rumpunen, K. (2014). Changes in content of major phenolic compounds during leaf development of sea buckthorn (Hippophae rhamnoides L.). Agric. Food Sci., 23, 207-219.

Rousi, A. (1971). The genus Hippophae L. A taxonomic study. Ann. Bot. Fenn., 8, 177-227.

Shipulina, L. D., Vichkanova, S. A., Sheichenko, O. P., Tolkachev, O. N. (1998). A medicinal remedy for treatment of virus diseases. Patent RU, No. 2118163, 27 April 1994. Application No. 94016333, registered 27 August 1998.

Skuridin, G. M., Chankina, O. V., Legkodymov, A. A., Kreimer, V. K., Baginskaya, N. V., Kutsenogii, K. P. (2014). Trace element composition of seabuckthorn (Hippophae rhamnoides L.) parts. In: Mörsel, J.-T., Zubarev, Y., Eagle, D. (eds.). Seabuckthorn - Research for a Promising Crop. BoD Print Norderstedt, pp. 67-71.

Suryakumar, G., Gupta, A. (2011). Medicinal and therapeutic potential of Sea buckthorn (Hippophae rhamnoides L.). J. Ethnopharm., 138, $268-278$.

\section{SMILTSĒRKŠĶU LAPAS UN JAUNĀS PĀRTIKAS NOVĒRTĒJUMS}

Ar jauno pārtiku apzīmē jebkuru pārtiku, kas Eiropas Savienībā lielos apjomos nav tikusi izmantota cilvēku patēriņam līdz 1997. gadam. Regula (EK) 258/97 par jauno pārtiku attiecas arī uz pārtikas produktiem un pārtikas produktu sastāvdạ̦ām, kuras satur vai ir izdalītas no augiem, iznemot pārtiku, kurai ir zināma vēsture par drošu lietošanu uzturā Eiropas Savienībā līdz 1997. gadam. Eiropas Savienībā līdz 1997. gadam nav informācijas par smiltsērkšķu (Hippophae rhamnoides L.) lapu izmantošanu nozīmīgos apjomos pārtikā, uztura bagātinātājos vai garšvielu veidā. Jauna likumdošana par jauno pārtiku (ES) 2015/2283 stāsies spēkā 2018. gada sākumā. Vēsturiska informācija par produktu tradicionālu, drošu lietošanu uzturā no trešajām pasaules valstīm tiks akceptēta. Tas nozīmē jaunās pārtikas izmantošanu patērētāju uzturā vismaz nākamos 25 gadus. Jaunās pārtikas pieteikums ietver produkta aprakstu, ražošanas procesu, informāciju par īpašībām un sastāvu, ieteicamos izmantošanas veidus un lietošanas daudzumu, ieteicamo devu, lietošanas vēsturi, absorbciju, sadalīšanos, metabolismu, uzturvērtību, toksikoloğisko informāciju un alerğiskumu. Smiltsērkšḳu lapas pēdējā laikā ir aktīvas izpētes procesā, jau ir pieejams liels informācijas apjoms, bet vēl nepieciešams drošības novērtējums atbilstošs jaunajai pārtikai. 